\title{
RADICAL SCAVENGING AND DISINFECTANT EFFECT OF ESSENTIAL OIL FROM MOROCCAN MENTHA PULEGIUM
}

\author{
MARWA CHRAIBI*, KAWTAR FIKRI BENBRAHIM, DOUAAE OU-YAHYIA, MOUNYR BALOUIRI, ABDELLAH FARAH \\ Sciences and Technology Faculty. Sidi Mohamed Ben Abdellah University, Morocco \\ Email: chraibi-marwa@outlook.com \\ Received: 27 Apr 2016 Revised and Accepted: 22 Jul 2016
}

ABSTRACT

Objective: As part of the valorization of medicinal and aromatic plants in Morocco, this study aims to investigate the chemical composition, the antimicrobial and the antioxidant activities of Mentha pulegium essential oil.

Methods: Essential oil of M. pulegium from Oued Laou region (Morocco) was screened for its antimicrobial activity against seven bacteria and two fungi using broth microdilution method. The radical scavenging effect was used to assess in vitro antioxidant capacity of this oil

Results: The tested essential oil exhibited strong inhibitory effect against all tested microorganisms with minimum inhibitory concentrations ranging from $0.003 \%$ to $1 \%(\mathrm{v} / \mathrm{v}$ ) except for Pseudomonas aeruginosa. Moreover, the studied essential oil exhibited radical scavenging power with the half maximal inhibitory concentration of $2 \mathrm{mg} / \mathrm{ml}$

Conclusion: These findings showed that the studied essential oil has both an antimicrobial and antioxidant potential, which is very rare. Thus, it reinforces its use as an effective, eco-friendly preservative agent in food and cosmetic field.

Keywords: Essential oil, Mentha pulegium, Antimicrobial, Antioxidant, Radical scavenging

(C) 2016 The Authors. Published by Innovare Academic Sciences Pvt Ltd. This is an open access article under the CC BY license (http://creativecommons. org/licenses/by/4. 0/) DOI: http://dx.doi.org/10.22159/ijpps.2016.v8i9.12434

\section{INTRODUCTION}

Essential oils and other plant extracts have evoked great interest as a potential source of bioactive phytochemical compounds. They have been extensively screened for their potential use as alternatives for food protection against lipid oxidation, as well as for the research of new antimicrobials to fight multi-drug resistant microorganisms.The genus Mentha includes 20 species that are widely distributed and can be found in many environments. Several published papers have reported the chemical profile of essential oils from $M$. pulegium of Iran [1], Greece [2], Turkey [3] and Portugal [4]. Moreover, species of Mentha have been used as folk remedy for the treatment of nausea, bronchitis, flatulence, anorexia, ulcerative colitis and liver complaints, due to their anti-inflammatory, carminative, antiemetic, diaphoretic, antispasmodic, analgesic, stimulant, emmenagogue and anticatharrhal activities [5].

Mentha pulegium, known as pennyroyal in Europe, is a herbaceous perennial plant which can reach $40 \mathrm{~cm}$ high [6]. It grows wildly in humid areas in Centre, East and West of Europe, North Africa and minor Asia [5]. In Morocco, it is very widespread, particularly between Marrakech and Azrou regions. M. pulegium is a fertile plant whose descendants seem fairly homogeneous. It can be distinguished from other mints species by its stretched port, highly branched stems which are spreading or lying on the soil, pink flowers arranged along the stem and branches and the closed chalice. At maturity, its glandular trichomes are responsible for the essential oil secretion. This oil has been reported by other works for it's insecticidal [7], antimicrobial [8], antioxidant [9] and anti-corrosive effects [10]

The present study aims to investigate the chemical composition of Moroccan M. pulegium essential oil, to assess its antimicrobial activity against seven bacteria and two fungi causing food-borne illness and other health threats as well as its capacity to scavenge the DPPH free radical.

\section{MATERIALS AND METHODS}

Plant material

Fresh aerial part of Mentha pulegium was harvested from Oued Laou region (35 ${ }^{\circ} 26^{\prime} 24 " \mathrm{~N}$; $5{ }^{\circ} 4{ }^{\prime} 48^{\prime \prime} \mathrm{W}$; $69 \mathrm{~m}$ altitude) in Morocco. The botanical identification was performed, and then voucher specimen was deposited at the Herbarium of National Institute of the Medicinal and Aromatic Plants (NIMAP), Morocco.

\section{Essential oil extraction}

The fresh aerial part of $M$. pulegium (leaves and stems) were hydrodistilled for $3 \mathrm{~h}$ using a Clevenger-type apparatus[11]. The essential oil was kept in dark at $4{ }^{\circ} \mathrm{C}$ until further use.

\section{Chemical analysis of essential oil}

The essential oil was analyzed using Gas chromatography (GC) coupled to mass spectrometry GC/MS (Polaris Q ion trap MS). Hence, analyses were performed on a Hewlett-Packard (HP 6890) gas chromatography (FID), equipped with a $5 \%$ phenyl methyl silicone HP-5 capillary column ( $30 \mathrm{~m} \times 0.25 \mathrm{~mm} \times$ film thickness $0.25 \mu \mathrm{m}$ ) The temperature was programmed from $50{ }^{\circ} \mathrm{C}$ after $5 \mathrm{~min}$ initial hold to $200{ }^{\circ} \mathrm{C}$ at $4{ }^{\circ} \mathrm{C} / \mathrm{min}$. Chromatography carrier gas was $\mathrm{N}_{2}(1.8$ $\mathrm{ml} / \mathrm{min}$ ), the split mode was used (Flow: $72.1 \mathrm{ml} / \mathrm{min}$, ratio: $1 / 50$ ), the temperature of injector and detector was $250{ }^{\circ} \mathrm{C}$, final hold time was $48 \mathrm{~min}$. The machine was led by a computer system type "HP Chem Station", managing its functioning and allowing to follow the evolution of chromatographic analyses. Diluted samples $(1 / 20$ in methanol) of $1 \mu \mathrm{l}$ were injected manually.

\section{Target strains}

Tested bacteria include seven isolates of Escherichia coli ATCC 25922, Pseudomonas aeruginosa ATCC 27853, Micrococcus luteus ATCC 14452, Staphylococcus aureus ATCC 29213, Bacillus subtilis ATCC 6633, Salmonella typhimurium and Bacillus cereus. Before use, strains were revivified by subcultures in Luria-Bertani (LB) plates (Biokar, France) at $37^{\circ} \mathrm{C}$ for $24 \mathrm{~h}$.

As regards to the tested yeast, they include Candida albicans and Candida tropicalis. Revivification was made by subculturing each strain in malt extract agar (Biokar, France) plates at $30{ }^{\circ} \mathrm{C}, 48 \mathrm{~h}$.

\section{Determination of minimum inhibitory concentration (MIC)}

The minimum inhibitory concentrations were determined in 96 well-microplate using the microdilution assay[12], with slight 
modifications. Bacteriological agar (Biokar, France) at 0.15\% (w/v) was used as an emulsifier of the essential oil in the culture medium. For bacteria, the essential oil was serially diluted in Muller Hinton broth (Biokar, France) supplemented with agar to obtain final concentrations ranging between $8 \%$ and $0.007 \%(\mathrm{v} / \mathrm{v})$. The $12^{\text {th }}$ well was considered as growth control (free essential oil control). Then, $50 \mu \mathrm{l}$ of bacterial inoculum, previously prepared and adjusted to 0.5 McFarland, were added to each well to reach the final concentration of $10^{6} \mathrm{CFU} / \mathrm{ml}$. After incubation at $37^{\circ} \mathrm{C}$ for $24 \mathrm{~h}, 10 \mu \mathrm{l}$ of resazurin (Sigma-Aldrich, Germany) were added to each well as a bacterial growth indicator. After further incubation at $37{ }^{\circ} \mathrm{C}$ for $2 \mathrm{~h}$, the bacterial growth was revealed by coloration change from purple to pink. Oxacillin $(5 \mu \mathrm{g} / \mathrm{ml})$ was used as a positive control. Experiments were carried out in triplicate.

For yeast, the microdilution was made according to the protocol previously described by CLSI [13], with slight modifications. Firstly, the essential oil was serially diluted in yeast extract-peptone-glucose broth (Biokar, France) (YPG), supplemented with agar at $0.15 \%$ $(\mathrm{w} / \mathrm{v})$, to achieve final concentrations ranging between 4 and 0.003 $\%(\mathrm{v} / \mathrm{v})$. The $12^{\text {th }}$ well was also considered as a growth control. Then, $50 \mu \mathrm{l}$ of inoculum were added to each well at the final concentration of $10^{3} \mathrm{CFU} / \mathrm{ml}$. Finally, the microplate was incubated at $30^{\circ} \mathrm{C}$ for 48 h. Experiments were carried out in triplicate.

\section{DPPH radical scavenging assay}

The capacity of M. pulegium essential oil to scavenge free radical was evaluated using a synthetic free radical molecule 1,1-diphenyl-2picrylhydrazyl (DPPH) (Sigma-Aldrich, Germany) [14]. Briefly, $3 \mathrm{ml}$ of each essential oil dilution $(0.5,1,2.5$, and $10 \mathrm{mg} / \mathrm{ml})$ prepared in methanol was mixed with $3 \mathrm{ml}$ of a methanolic solution of DPPH $0.004 \%(\mathrm{w} / \mathrm{v})$. The mixtures were vortexed and kept in the dark for $30 \mathrm{~min}$. The absorbance was measured at $517 \mathrm{~nm}$, using Vis-UV spectrophotometer. BHT was used as positive control.

The antioxidant activity was calculated as follows:

$$
\text { Antioxidant activity }(\%)=\frac{\mathrm{Abs}_{\text {control }}-\mathrm{Abs}_{\text {sample }}}{\mathrm{Abs}_{\text {control }}} \times 100
$$

\section{RESULTS AND DISCUSSION}

\section{Antimicrobial activity}

The studied essential oil has been previously subjected to the gas chromatography-mass spectrometry analysis. Eighteen compounds accounting for $98.77 \%$ of the M. pulegium essential oil were identified. Its major constituents were $\mathrm{R}(+)$-pulegone $(75.48 \%)$ (fig. $1)$, carvone $(6.66 \%)$ and dihydrocarvone $(4.64 \%)$. Beside other compounds with relatively low levels, including $p$-mentha-3,8-diene
(2.44\%), limonene (1.88\%), Pino Carbone (1.27\%), $\alpha$-peperitone $(1.13 \%)$ and octanol-3 $(1.86 \%)$ were found. It is observed that this essential oil was characterized by the presence of pulegone as the main component. These results are similar to the most previous reports on Moroccan M. pulegium [15].

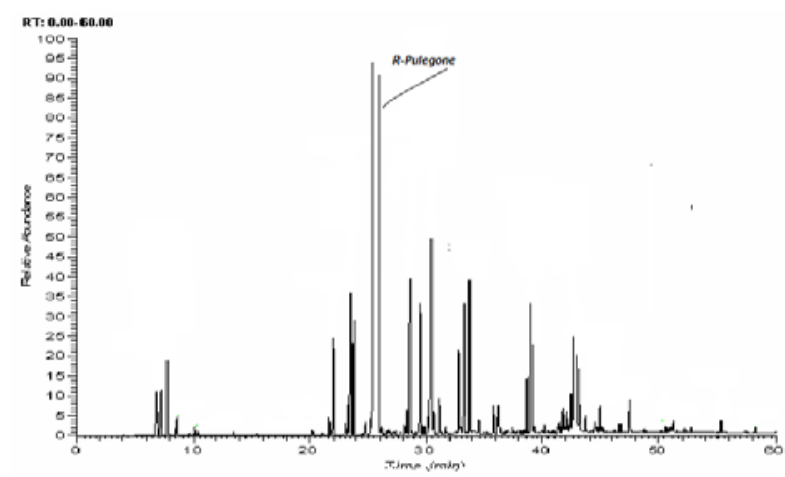

Fig. 1: Chromatogram of Mentha pulegium essential oil

The antimicrobial activity tested in vitro by microdilution method showed that the tested oil exhibited a strong antimicrobial activity against all tested strains except $P$. aeruginosa (table 1 ). It can also be noted that this inhibitory effect depends on the target strain. Indeed, $M$. luteus and B. cereus were most susceptible to the tested essential oil: they were inhibited from very low concentration $(0.125 \% \mathrm{v} / \mathrm{v})$. Moreover, the growth of $S$. aureus and B. subtilis was inhibited from the concentrations of $0.5 \%$ and $0.25 \%$ respectively. For the Gramnegative bacteria (S. typhi and E. coli), a MIC value of $0.5 \%$ (v/v) was required. It is important to note that all tested strains were resistant to oxacillin at $5 \mu \mathrm{g} / \mathrm{ml}$ except Staphylococcus aureus, Bacillus subtilis and Micrococcus luteus. The results of essential oils antimicrobial activity are in agreement with several works, which reported that Gram-negative bacteria are generally more resistant than the Grampositive ones [16]. This finding could be due to the penetrating ability of essential oils into the cell, and more precisely to the difference of their cell wall compositions. In fact, the outer membrane of Gram-negative bacteria presents a hydrophilic barrier consisting of lipopolysaccharides molecules, which makes them protected against the effects of this kind of compounds [17]. However, Gram-positive bacteria are less protected against antibacterial agents; the peptidoglycan prevents the passage of molecules with a molecular weight more than $50 \mathrm{KD}$ [18].

Table 1: The minimum inhibitory concentrations (MIC) of M. pulegium essential oil against bacterial strains tested

\begin{tabular}{|c|c|c|c|c|c|c|c|c|c|c|c|c|}
\hline \multirow[t]{2}{*}{ Strains } & \multicolumn{11}{|c|}{ Concentrations \% (v/v) } & \multirow{2}{*}{$\begin{array}{l}\text { Oxacillin } \\
5 \mu \mathrm{g} / \mathrm{ml}\end{array}$} \\
\hline & 8 & 4 & 2 & 1 & 0.5 & 0.25 & 0.125 & 0.062 & 0.031 & 0.015 & 0.007 & \\
\hline Staphylococcus aureus & - & - & - & - & - & + & + & + & + & + & + & + \\
\hline Bacillus subtilis & - & - & - & - & - & - & + & + & + & + & + & + \\
\hline Bacillus cereus & - & - & - & - & - & - & - & + & + & + & + & - \\
\hline Micrococcus luteus & - & - & - & - & - & - & - & + & + & + & + & + \\
\hline Escherichia coli & - & - & - & - & + & + & + & + & + & + & + & - \\
\hline Salmonella typhi & - & - & - & - & + & + & + & + & + & + & + & - \\
\hline Pseudomonas aeruginosa & + & + & + & + & + & + & + & + & + & + & + & - \\
\hline
\end{tabular}

As regard to the fungal strains, the pennyroyal's essential oil exhibited a remarkable antifungal effect against both yeast strains tested with a MIC value of $0.031 \%(\mathrm{v} / \mathrm{v})$ (table 2).

Table 2: The minimum inhibitory concentration (MIC) of M. pulegium essential oil against fungal strains

\begin{tabular}{|c|c|c|c|c|c|c|c|c|c|c|c|}
\hline \multirow{2}{*}{ Strains } & \multicolumn{11}{|c|}{ Concentrations \% (v/v) } \\
\hline & 4 & 2 & 1 & 0.5 & 0.25 & 0.125 & 0.062 & 0.031 & 0.015 & 0.007 & 0.003 \\
\hline Candida albicans & - & - & - & - & - & - & - & - & + & + & + \\
\hline Candida tropicalis & - & - & - & - & - & - & - & - & + & + & + \\
\hline
\end{tabular}


Several studies have confirmed the antiseptic properties of $M$. pulegium essential oil. In fact, the antiseptic effect of this oil against Staphylococcus aureus, Staphylococcus epidermidis, Aspergillus niger, Candida albicans, Listeria monocytogenes and Vibrio cholera has been reported [16]. Likewise, a strong effect of this essential oil against microbial strains namely: Staphylococcus aureus, Bacillus subtilis, Escherichia coli and Klebsiella pneumonia has been proved [19].

The antimicrobial activity of this essential oil could be due to its chemical constituents. It is clear that our essence is characterized by the dominance of pulegone (75\%), which is a ketone known for its inhibitory effect [20]. In fact, various biological properties of pulegone have been reported, including antibacterial, antifungal, antihistaminic, antipyretic, anti-treponemal, convulsant, hypercholesterolemic, cytochrome P-450 inhibitory and lysozymal enzyme inhibitory effects [21].

Being a major compound for several medicinal herbs like $M$. longifolia [22], the pulegone has been reported as an antimicrobial [23]. Also, several works demonstrated that the carvone exerts an antimicrobial power against a wider range of bacteria and fungi [24, 25]. In addition, the synergistic effect of minor compounds and between all chemical constituents of the essential oil could be responsible for its antimicrobial outcome [26].

\section{Antioxidant activity}

The antioxidant activity of the studied essential oil was evaluated by the DPPH• reduction method using butylated hydroxytoluene (BHT) as standard.

As shown in fig. 2, a linear relationship was found between the antioxidant activity and the BHT concentration (R-square=0.99, $P$ value $=0.000$ ). The $\mathrm{IC}_{50}$ of the standard was of $6.83 \mu \mathrm{g} / \mathrm{ml}$. The essential oil investigated showed a scavenging effect with an IC $5_{50}$ of $2 \mathrm{mg} / \mathrm{ml}$. Hence, the result expressed with the equivalent of BHT was $3.42 \mu \mathrm{g}$ Eq BHT/mg of essential oil.

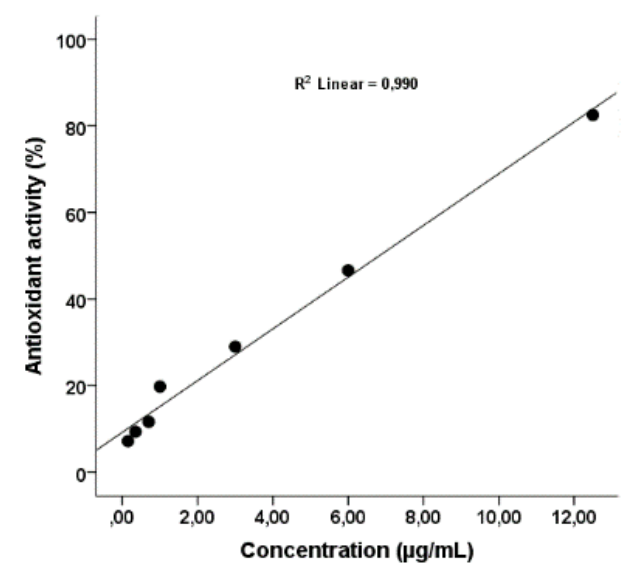

Fig. 2: Linear relationship between the antioxidant activity and the concentration of BHT

According to this finding, the whole essential oil exhibits an interesting radical scavenging effect even if the BHT was more active. However, the synthetic antioxidants have fallen out of favor because they are suspected of being carcinogenic and allergic [27].

Previous studies reported a wide variation in the antioxidant activity of $M$. pulegium essential oil. In fact, it showed significant antioxidant activity, in comparison to that obtained in Iran [28] and Portugal [4]. This antioxidant activity of $M$. pulegium essential oil is probably due to the ability of terpenes to be a donor of hydrogen atoms or electrons, and to capture free radicals [29].

\section{CONCLUSION}

To summarize, the present study revealed the interesting antimicrobial effect of $M$. pulegium essential oil with a broad spectrum. Moreover, a significant antioxidant activity of this oil assessed in vitro via the DPPH radical scavenging assay was found.
Hence, both activities demonstrated by the same oil shows its major interest to develop a new eco-friendly and safe preservative for the extension of the shelf-life of raw and processed foods. However, further studies should be carried out to evaluate the safety and toxicity of this essential oil.

\section{CONFLICT OF INTERESTS}

We certify that there is no conflict of interest with any financial organization regarding the material discussed in the manuscript

\section{REFERENCES}

1. Aghel N, Yamini Y, Hadjiakhoondi A, Pourmortazavi SM. Supercritical carbon dioxide extraction of Mentha pulegium L. essential oil. Talanta 2004;62:407-11.

2. Petrakis EA, Kimbaris AC, Pappas CS, Tarantilis PA, Polissiou MG. Quantitative determination of pulegone in pennyroyal oil by FT-IR spectroscopy. J Agric Food Chem 2009;57:10044-8.

3. Muller-Riebau F, Berger B, Yegen O, Cakir C. Seasonal variations in the chemical compositions of essential oils of selected aromatic plants growing wild in Turkey. J Agric Food Chem 1997;45:4821-5.

4. Teixeira B, Marques A, Ramos C, Batista I, Serrano C, Matos O, Neng NR, et al. European pennyroyal (Mentha pulegium) from Portugal: chemical composition of essential oil and antioxidant and antimicrobial properties of extracts and essential oil. Ind Crops Prod 2012;36:81-7.

5. Hajlaoui H, Trabelsi N, Noumi E, Snoussi M, Fallah H, Ksouri R, Bakhrouf A. Biological activities of the essential oils and methanol extract of town cultivated mint species (Mentha longifolia and Mentha pulegium) used in the Tunisian folkloric medicine. World J Microbiol Biotechnol 2009;25:2227-38.

6. Stengele M, Stahl-Biskup E. Glycosidically bound volatiles in peppermint (Mentha piperita L.). J Essent Oil Res 1993;5:13-9.

7. Barros G, Magro A, Conceição C, Matos O, Barbosa A, Bastos MS M, Mexia A. The use of Laurus nobilis and Mentha pulegium essential oils against Sitophilus zeamais (Coleoptera : Curculionidad on stored maize. Rev Ciências Agrárias 2015;38:191-5.

8. Sadeghi E, Mohammadi A, Jamilpanah M, Bashiri M, Bohlouli S, AWT_TAG. Antimicrobial Effects of Mentha pulegium Essential Oil on Listeria monocytogenes in Iranian White Cheese. J Food Qual Hazards Control 2016;3 : 20-4.

9. Silva LF, Cardoso G, Batista LR, Gomes MDS, Milani L, Rodrigues A, Aparecida D, Selvati DC, Teixeira ML, Schleiden M, Carvalho S, Santiago JDA, Nelson DL. Chemical Characterization, Antibacterial and Antioxidant Activities of Essential Oils of Mentha viridis L. and Mentha pulegium L. Am. J Plant Sci 2015;6:666-75.

10. Khadraoui A, Khelifa A, Hadjmeliani M, Mehdaoui R, Hachama K, Tidu A, Azari Z. Extraction, characterization and anticorrosion activity of Mentha pulegium oil: Weight loss, electrochemical, thermodynamic and surface studies. J Mol Liq 2016;216:724-31.

11. Haloui T, Farah A, Balouiri M, Chraibi M, Fadil M, Benbrahim K et al. Bacteriostatic and bactericidal profile of leaves and twigs essential oils of moroccan Pistacia lentiscus L. J Appl Pharm Sci 2015;5:50-3.

12. Balouiri M, Sadiki M, Ibnsouda SK. Methods for in vitro evaluating antimicrobial activity: a review. J Pharm Anal 2016;6:71-9.

13. CLSI. Reference Method for Broth Dilution Antifungal Susceptibility Testing of Yeasts; Approved Standard. 2nd Edition. Serving the World's Medical Science Community Through Voluntary Consensus. The National Committee for Clinical Laboratory Standards; 2002.

14. Ouedrhiri W, Bouhdid S, Balouiri M, El Ouali Lalami A, Moja S, Ouazzani Chahdi F, et al. Chemical composition of Citrus aurantium L. leaves and zest essential oils, their antioxidant, antibacterial single and combined effects. J Chem Pharm Res 2015;7:78-84.

15. Hmiri S, Rahouti M, Habib Z, Satrani B. Huiles essentielles de Mentha Pulegium Et D'Eucalyptus camaldulensis dans la lutte biologique contre les champignons responsible de la deterioration des pommes. Bull Soc R Sci Liege 2011;80:824-36.

16. Mahboubi M, Haghi G. Antimicrobial activity and chemical composition of Mentha pulegium L. essential oil. J Ethnopharmacol 2008;119:325-7. 
17. Nikaido $\mathrm{H}$. Molecular basis of bacterial outer membrane permeability revisited. Microbiol Mol Biol Rev 2003;67:593-656.

18. Hogan D, Kolter R. Why are bacteria refractory to antimicrobials. Curr Opin Microbiol 2002;5:472-7.

19. Brahmi F, Abdenour A, Bruno M, Silvia P, Alessandra P, Danilo $\mathrm{F}$, et al. Chemical composition and in vitro antimicrobial, insecticidal and antioxidant activities of the essential oils of Mentha pulegium L. and Mentha rotundifolia (L.) Huds are growing in Algeria. Ind Crops Prod 2016;88:96-105.

20. Satrani B. Valorisation de plantes aromatiques et médicinales du Maroc. Éditions universitaires européennes EUE; 2010. p. 160.

21. Baser KHC, Kirimer N, Tümen G. Pulegone-rich essential oils of turkey. J Essent Oil Res 1998;10:1-8.

22. Gulluce M, Sahin F, Sokmen M, Ozer H, Daferera D, Sokmen A, Polissiou M, et al. Antimicrobial and antioxidant properties of the essential oils and methanol extract from Mentha longifolia L. ssp. longifolia. Food Chem 2007;103:1449-56.

23. Bakkali F, Averbeck S, Averbeck D, Idaomar M. Biological effects of essential oils a review. Food Chem Toxicol 2008;46:446-75.

24. Lis-Balchin M, Deans SG. Antimicrobial effects of hydrophilic extracts of Pelargonium species (Geraniaceae). Lett Appl Microbiol 1996;23:205-7.

25. Aggarwal K, Khanuja S, Ahmad A, Santha Kumar T, Gupta VK, Kumar S. Antimicrobial activity profiles of the two enantiomers of limonene and carvone isolated from the oils of Mentha spicata and Anethum sowa. Flavour Fragr J 2002;17:59-63.

26. Lahlou M. Methods to study the phytochemistry and bioactivity of essential oils. Phyther Res 2004;18:435-48.

27. Bohme K, Barros-Velazquez J, Calo-Mata P, Aubourg PS. The antibacterial, antiviral and antifungal activity of essential oils: mechanisms and applications. In: Villa $\mathrm{T}$, Veiga-Crespo $\mathrm{P}$. editors. Antimicrob. Compd. Berlin, Heidelberg: SpringerVerlag Berlin Heidelberg; 2014. p. 269-84.

28. Kamkar A, Javan AJ, Asadi F, Kamalinejad M. The antioxidative effect of Iranian Mentha pulegium extracts and essential oil in sunflower oil. Food Chem Toxicol 2010;48:1796-800.

29. Ouakouak H, Chohra M, Denane M. Chemical composition, antioxidant activities of the essential oil of Mentha pulegium L, South East of Algeria. Int Lett Nat Sci 2015;39:49-55.

\section{How to cite this article}

- Marwa Chraibi, Kawtar Fikri Benbrahim, Douaae Ou-Yahyia, Mounyr Balouiri, Abdellah Farah. Radical scavenging and disinfectant effect of essential oil from moroccan Mentha pulegium. Int J Pharm Pharm Sci 2016;8(9):116-119. 